\title{
Multiresistant extended-spectrum $\beta$-lactamase- producing Enterobacteriaceae from humans, companion animals and horses in central Hesse, Germany
}

\author{
Judith Schmiedel ${ }^{1}$, Linda Falgenhauer ${ }^{1}$, Eugen Domann ${ }^{1}$, Rolf Bauerfeind ${ }^{2}$, Ellen Prenger-Berninghoff ${ }^{2}$, \\ Can Imirzalioglu ${ }^{1 *}$ and Trinad Chakraborty ${ }^{1}$
}

\begin{abstract}
Background: Multiresistant Gram-negative bacteria producing extended-spectrum $\beta$-lactamases (ESBLs) are an emerging problem in human and veterinary medicine. This study focused on comparative molecular characterization of $\beta$-lactamase and ESBL-producing Enterobacteriaceae isolates from central Hesse in Germany. Isolates originated from humans, companion animals (dogs and cats) and horses.

Results: In this study $153(83.6 \%)$ of the human isolates $(n=183)$ and $163(91.6 \%)$ of the animal isolates $(n=178)$ were confirmed as ESBL producers by PCR and subsequent sequencing of the PCR amplicons. Predominant ESBL subtypes in human and animal samples were CTX-M-15 (49.3\%) and CTX-M-1 (25.8\%) respectively. Subtype bla almost exclusively in equine and was absent from human isolates. The carbapenemase OXA-48 was detected in 19 ertapenem-resistant companion animal isolates in this study. The Plasmid-encoded quinolone resistance (PMQR) gene aac('6)- $\mathrm{Ib}$ - $\mathrm{Cr}$ was the most frequently detected antibiotic- resistance gene present in $27.9 \%$ of the human and $36.9 \%$ of the animal ciprofloxacin-resistant isolates. Combinations of two or up to six different resistance genes (penicillinases, ESBLs and PMQR) were detected in 70\% of all isolates investigated. The most frequent species in this study was Escherichia coli (74\%), followed by Klebsiella pneumoniae (17.5\%), and Enterobacter cloacae (4.2\%). Investigation of Escherichia coli phylogenetic groups revealed underrepresentation of group B2 within the animal isolates.
\end{abstract}

Conclusions: Isolates from human, companion animals and horses shared several characteristics regarding presence of ESBL, PMQR and combination of different resistance genes. The results indicate active transmission and dissemination of multi-resistant Enterobacteriaceae among human and animal populations.

Keywords: ESBL, Enterobacteriaceae, Comparison, Human isolates, Animal isolates, One Health concept

\section{Background}

Extended-spectrum beta-lactamase (ESBL)-producing Enterobacteriaceae are isolated with increasing frequency from human and animal samples. In particular, the species Escherichia (E.) coli plays an important role as a source of the corresponding resistance genes [1]. ESBLs genes are commonly plasmid-encoded and can easily be transmitted

\footnotetext{
* Correspondence: Can.imirzalioglu@mikrobio.med.uni-giessen.de ${ }^{1}$ Institute of Medical Microbiology, Justus Liebig University Giessen and German Center for Infection Research (DZIF), Partner site

Giessen-Marburg-Langen, Schubertstrasse 81, 35392 Giessen, Germany Full list of author information is available at the end of the article
}

by conjugation to other bacteria, even across species barriers. In addition, various resistance genes are located in or close to mobile genetic elements such as insertion sequences and transposons [2]. Lateral gene transfer and continuous DNA recombination make it extremely difficult to track transmission pathways of ESBL genes in bacterial populations. The transmission of ESBL-producing pathogens or ESBL genes between companion animals/livestock and owner/caretaker/consumer is currently a subject of intense and controversial discussion. Evidence has been presented for zoonotic 
spread $[3,4]$. Several studies have addressed the risk of infection that could arise from keeping animals [5-7]. A recent study highlighted that the risk factors for ESBL carriage were travel to Greece or Africa within the last 12 months and keeping of pet animals, but not antibiotic consumption or recent hospitalization [8]. Until now, it is still difficult to estimate the amount of exchange and even more difficult to define the risk for human and animal health and also food safety.

The focus of this study was a comparative investigation of 361 ESBL-producing Enterobacteriaceae isolates obtained from animals and human patients presenting at a veterinary clinic and a hospital, respectively, both serving a similar catchment area. The prevalence of $\beta$-lactamase-, particularly ESBL-producing bacteria in companion animal, horse and human isolates of clinical origin was examined. Resistance genes ( $\beta$-lactamase and plasmid-mediated quinolone resistance (PMQR)) and E. coli phylogenetic groups were investigated using molecular methods.

This work sheds light on shared populations of ESBLproducing Enterobacteriaceae in symptomatic companion animals, horses and humans in the geographical region of middle Hesse, Germany.

\section{Methods}

\section{Bacterial isolates}

A collection of 513 Enterobacteriaceae isolates resistant to one or more third-generation cephalosporins (200 human isolates and 313 animal isolates) was examined. Identification was done using in-house biochemical tests. In case of ambiguous results confirmation was done using API 20E. Prior to further analysis, all isolates were grown on MacConkey agar supplemented with cefotaxime $(2 \mathrm{mg} / \mathrm{l})$ to promote selection of $\beta$-lactamase producers and ensure selection of Enterobacteriaceae. Afterwards isolates were tested for possible ESBL production by double disc synergy test (DDST) according to EUCAST guidelines for resistance mechanisms [9]. After performance of the DDST 183 human and 178 animal isolates were categorized as possible ESBL-producers and forwarded for a more detailed investigation. Isolates with a negative DDST result were not included in the study.

DDST-positive isolates from human clinical samples $(n=183)$ were taken from the strain collection of the Institute of Medical Microbiology, Giessen. Some of the isolates originate from routine screening for colonization with ESBL-producing Enterobacteriaceae at the University hospital Giessen. Additional isolates were collected from samples of clinically ill patients e.g. blood culture or urine samples in the same facility. All isolates were collected between 2009 and 2010. Approximately two-thirds of the human isolates originated from inpatients $(n=128)$ and one third were isolates from outpatients wards $(n=55)$.
DDST-positive isolates from animals $(\mathrm{n}=178)$ were obtained during a survey for aerobic Gram-negative bacteria growing on MacConkey agar supplemented with cefotaxime $(2 \mathrm{mg} / \mathrm{l})$ among animal patients at the veterinary clinics of the Justus Liebig University (JLU) Giessen. All samples were clinically relevant infection related isolates. The isolates originated from horses $(n=100)$, dogs $(n=67)$ and cats $(n=11)$ and were collected between 2009 and 2011.

The study was approved by the ethics committee of medical faculty of the Justus Liebig University of Giessen and deemed exempt from informed consent.

\section{Antibiotic susceptibility}

Antibiotic susceptibility testing was done using the VITEK $^{\circ} 2$ compact system with AST N117 cards (Biomérieux) and Etest ${ }^{\circ}$ stripes (Liofilchem ${ }^{\circ}$ ) containing ertapenem, cefepime, chloramphenicol and nalidixic acid. Results were evaluated according to CLSI guidelines for human pathogens (CLSI, 2012).

\section{$\beta$-lactamase identification}

For antibiotic resistance genes screening by PCR and identification by sequencing were performed as described previously [10]. Specific oligonucleotide primers for $b l a_{\mathrm{TEM}}$, $b l a_{\mathrm{SHV}}[11], b l a_{\mathrm{CTX}-\mathrm{M}}$ genes [12] and bla $a_{\mathrm{OXA}-1}$ [13] were used. The MAST carbapenemase detection set (MAST group, UK) was applied on carbapenem-resistant isolates. Furthermore, primers for $b l a_{\text {OXA-48 }}$ were used for carbapenem-resistant isolates [11]. With the exception

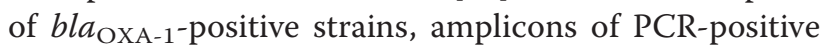
strains were sequenced to identify the encoded ESBL allele in detail. Sequencing was performed using the automated sequencer ABI Prism 3100 (Life technologies, USA). The blastn algorithm of NCBI (http://www.ncbi. nlm.nih.gov/blast/) was used for database searches to identify the resistance gene allele. The primers and the sequences they were derived from are presented in Table 1. Positive control strains from the Institute of Microbiology, Giessen, Germany, were Klebsiella (K.) pneumoniae $\mathrm{H} 59$ for $b l a_{\mathrm{TEM}}, b l a_{\mathrm{SHV}}, b l a_{\mathrm{CTX}-\mathrm{M}}, b l a_{\mathrm{OXA}-1}$ and aac(6')-Ib, Klebsiella pneumoniae 714 for bla $a_{\mathrm{OXA}-48}$. For the qnr-genes, strains from the Institute of Hygiene and Infectious Diseases of Animals, Giessen, Germany (V148 for $q n r A$, V167 for $q n r B$, V60 for $q n r D$ and V61 for $q n r S)$, were used as positive controls after sequencing and comparison with known sequences using DNASTAR software (DNASTAR Inc, Madison, USA) and the NCBI blastn algorithm.

\section{Detection of Plasmid-encoded quinolone resistance (PMQR)}

Detection for PMQR by PCR was performed on all isolates with a minimum inhibitory concentration $(\mathrm{MIC}) \geq$ 
Table 1 PCR primers used to detect $\beta$-lactamase genes, PMQR genes and $E$. coli phylogenetic groups

\begin{tabular}{|c|c|c|c|c|}
\hline Primer & Sequence $\left(5^{\prime}-3^{\prime}\right)$ & Target & Size of product (bp) & Reference \\
\hline TEM_f & ATGAGTATTCAACATTTCCG & $b l a_{\mathrm{TEM}}$ & 851 & [11] \\
\hline TEM_r & TTAATCAGTGAGGCACCTAT & & & \\
\hline $\mathrm{SHV}_{-} \mathrm{f}$ & GCAAAACGCCGGGTTATTC & $b l a_{\mathrm{SHV}}$ & 940 & [11] \\
\hline SHV_r & GGTTAGCGTTGCCAGTGCT & & & \\
\hline CTX-M_f & TCTTCCAGAATAAGGAATCCC & $b / a_{\subset T X-M}$ & 909 & [12] \\
\hline CTX-M_r & CCGTTTCCGCTATTACAAAC & & & \\
\hline OXA-1_f & AGCAGCGCCAGTGCATCA & $b / a_{O \times A-1}$ & 700 & [13] \\
\hline OXA-1_r & ATTCGACCCCAAGTTTCC & & & \\
\hline OXA-48_f & AAATCACAGGGCGTAGTTGTG & bla OXA-48 & 555 & [11] \\
\hline OXA-48_r & GACCCACCAGCCAATCTTAG & & & \\
\hline qnrA_f & AGAGGATTTCTCACGCCAGG & qnrA & 619 & [14] \\
\hline qnrA_r & GCAGCACTATKACTCCCAAGG & & & \\
\hline qnrB_f & GGMATHGAAATTCGCCACTG & $q n r B$ & 264 & [16] \\
\hline qnrB_r & TTTGCYGYYCGCCAGTCGAA & & & \\
\hline $\operatorname{qnrC} f$ & GGGTTGTACATTATTGAATC & gnrC & 447 & [17] \\
\hline qnrC_r & TCCACTITACGAGGTTCT & & & \\
\hline qnrD_f & CGAGATCAATTTACGGGGAATA & anrD & 582 & [18] \\
\hline qnrD_r & AACAAGCTGAAGCGCCTG & & & \\
\hline qnrs_f & GCAAGTTCATTGAACAGGCT & qnrs & 428 & [16] \\
\hline qnrS_r & TCTAAACCGTCGAGTTCGGCG & & & \\
\hline qepA_f & CTGCAGGTACTGCGTCATG & qepA & 403 & [15] \\
\hline qepA_r & CGTGTTGCTGGAGTTCTTC & & & \\
\hline aac_f & TTGCGATGCTCTATGAGTGGCTA & $a a c\left(6^{\prime}\right)-1 b$ & 482 & [19] \\
\hline$a a c \_r$ & CTCGAATGCCTGGCGTGTTT & & & \\
\hline chuA.1 & GACGAACCAACGGTCAGGAT & chuA & 279 & [21] \\
\hline chuA.2 & TGCCGCCAGTACCAAAGACA & & & \\
\hline YjaA.1 & TGAAGTGTCAGGAGACGCTG & yajA & 211 & {$[21]$} \\
\hline YjaA.2 & ATGGAGAATGCGTTCCTCAAC & & & \\
\hline TspE4C2.1 & GAGTAATGTCGGGGCATTCA & TspE4C2 & 152 & {$[21]$} \\
\hline TspE4C2.2 & CGCGCCAACAAAGTATTACG & & & \\
\hline
\end{tabular}

$1 \mu \mathrm{g} / \mathrm{ml}$ for ciprofloxacin (Human isolates: $\mathrm{n}=140$, animal isolates: $\mathrm{n}=122)$. Oligonucleotide primers for detection of $q n r A, q n r B, q n r C, q n r D, q n r S, q e p A$ and $a a c\left(6^{\prime}\right)-I b$ were used [14-19]. Identification of the $\operatorname{aac}\left(6^{\prime}\right)-\mathrm{Ib}-\mathrm{cr}$ variant was performed according to Jones et al. 2008 [20].

Phylogenetic groups of ESBL-producers

Distribution of $E$. coli phylogenetic groups was analysed by PCR targeting genes chuA, yjaA and the DNA fragment TSPE4.C2 to assign the strains to the groups A, B1, B2 and D according to Clermont et al. 2000 [21].

Analysis of resistance genes patterns

Information regarding the source of isolates, species and the resistance genes detected were assembled into an Excel file. The data was subsequently analysed using GENE-E [22] which enables the clustering of data with matrix visualization and analysis to support visual data exploration.

\section{Results}

Overview of bacterial species

The majority of the isolates studied were E. coli $(74 \%)$, followed by K. pneumoniae (17.5\%) and Enterobacter cloacae (4.2\%). Other species detected were Klebsiella oxytoca, Enterobacter intermedius, Citrobacter freundii, Providencia stuartii, Morganella morganii and Proteus mirabilis. The percentages of E. coli and K. pneumoniae isolates among the human and animal isolates were very similar. 


\section{Resistance rates}

All isolates $(n=361)$ were categorised as multidrug resistant (MDR) according to the international expert proposal for interim standard definitions for acquired resistance promoted by the ECDC [23]. Both human $(n=183)$ and animal isolates $(n=178)$ revealed resistance against ampicillin and trimethoprim/sulfmethoxazole. Slight differences could be observed concerning the tested third generation cephalosporins ceftazidime, cefotaxime and cefepime. Of the human isolates $52.5 \% \quad(\mathrm{n}=96)$ showed resistance against ceftazidime, 78.7\% $(\mathrm{n}=144)$ resistance against cefotaxime and $98.4 \%(\mathrm{n}=180)$ resistance against cefepime. Of the animal isolates $75.8 \%(n=135)$ displayed resistance against ceftazidime and $99.4 \%(\mathrm{n}=177)$ to cefotaxime and cefepime. Of the human isolates $2.2 \%(n=4)$, and $1.1 \%$ $(n=2)$ of the animal isolates revealed resistance against imipenem. Resistance against the other tested carbapenem (ertapenem) was detected in $24.5 \%(n=45)$ of human isolates and in $19.7 \%(\mathrm{n}=35)$ of animal isolates. The aminoglycosides gentamicin and amikacin differed in their results.
Only 5.1\% $(\mathrm{n}=9)$ of animal isolates exhibited resistance against amikacin, as compared to $14.8 \%(n=27)$ of the human isolates. The resistance rates against gentamicin were higher in both cases with $35 \%(\mathrm{n}=64)$ in human isolates and $62.4 \%(n=111)$ in animal isolates. High resistance rates in both groups were also revealed for the fluoroquinolone ciprofloxacin $(76.5 \%(n=140)$ of the human isolates and $68.5 \%(n=122)$ of the animal isolates).

\section{Distribution of $\beta$-lactamases}

Almost all isolates carried at least one beta-lactamase (bla)-gene (Table 2). In all, 91.6\% of the animal isolates and $83.6 \%$ of the human isolates were confirmed as ESBL producers by PCR and sequencing. The remaining isolates $(7.5 \%)$ were negative for the presence of $b l a_{\mathrm{TEM}}$, $b l a_{\mathrm{SHV}}, b l a_{\mathrm{OXA}-1}, b l a_{\mathrm{OXA}-48}$ and $b l a_{\mathrm{CTX}-\mathrm{M}}$.

\section{CTX-M}

Subtypes of the ESBL CTX-M were by far the most frequently encoded ESBLs in both groups (Table 2 and

Table 2 Distribution of $\beta$-lactamase genes in Enterobacteriaceae isolates $(n=361)$ of human and animal origin

\begin{tabular}{|c|c|c|c|c|c|c|}
\hline \multirow[t]{2}{*}{ Source } & \multicolumn{2}{|c|}{ Human } & \multicolumn{3}{|c|}{ Animal } & \multirow[b]{2}{*}{ Total no. of isolates } \\
\hline & Outpatients & Inpatients & Dogs & Cats & Horses & \\
\hline No. of isolates ${ }^{a}$ & 55 & 128 & 67 & 11 & 100 & 361 \\
\hline \multicolumn{7}{|l|}{ Penicillinases $^{b}$} \\
\hline$b / a_{\text {TEM }-1}$ & $58.2(32)$ & $41.4(53)$ & $62.7(42)$ & $45.5(5)$ & $67(67)$ & $55.1(199)$ \\
\hline$b / a_{\text {TEM-190 }}$ & & & $1.5(1)$ & & & $0.3(1)$ \\
\hline$b / a_{\mathrm{SHV}-1}$ & & $2.3(3)$ & $16.4(11)$ & & $2(2)$ & $4.4(16)$ \\
\hline$b / a_{\mathrm{SHV}-11}$ & & $1.6(2)$ & & & & $0.6(2)$ \\
\hline$b l a_{\mathrm{OXA}-1}$ & $23.6(13)$ & $32.8(42)$ & $59.7(40)$ & $45.5(5)$ & $29(29)$ & $35.7(129)$ \\
\hline \multicolumn{7}{|l|}{$\mathrm{ESBL}^{\mathrm{b}}$} \\
\hline bla $a_{\text {TEM }-52}$ & & $2.3(3)$ & & & & $0.8(3)$ \\
\hline$b l a_{\mathrm{SHV}-2}$ & & & $1.5(1)$ & $9.1(1)$ & & $0.6(2)$ \\
\hline$b / a_{\mathrm{SHV}-5}$ & & $0.8(1)$ & & & & $0.3(1)$ \\
\hline$b / a_{\mathrm{SHV}-28}$ & & & $3(2)$ & & $1(1)$ & $0.8(3)$ \\
\hline bla $a_{\mathrm{CTX}-\mathrm{M}-1}$ & $32.7(18)$ & $45.3(24)$ & $16.4(11)$ & $27.3(3)$ & $37(37)$ & $25.8(93)$ \\
\hline$b / a_{C T X-M-2}$ & & & & $9.1(1)$ & $15(15)$ & $4.4(16)$ \\
\hline$b l a_{\text {CTX-M-9 }}$ & & & $3(2)$ & $9.1(1)$ & $1(1)$ & $1.1(4)$ \\
\hline$b / a_{\mathrm{CTX}-\mathrm{M}-14}$ & & & $1.5(1)$ & & & $0.3(1)$ \\
\hline$b l a_{\mathrm{CTX}-\mathrm{M}-15}$ & $54.5(30)$ & $51.6(66)$ & $59.7(40)$ & $36.4(4)$ & $38(38)$ & $49.3(178)$ \\
\hline$b / a_{\text {CTX-M-32 }}$ & $1.8(1)$ & $0.8(1)$ & & & & $0.6(2)$ \\
\hline$b / a_{\mathrm{CTX}-\mathrm{M}-38}$ & & $0.8(1)$ & & & & $0.3(1)$ \\
\hline bla & $1.8(1)$ & $2.3(3)$ & & & $1(1)$ & $1.4(5)$ \\
\hline bla & $1.8(1)$ & & & & $3(3)$ & $1.1(4)$ \\
\hline$b l a_{\mathrm{CTX}-\mathrm{M}-117}$ & & $0.8(1)$ & & & & $0.3(1)$ \\
\hline \multicolumn{7}{|l|}{ Carbapenemases $^{\mathbf{b}}$} \\
\hline bla ${ }_{\mathrm{OXA}-48}$ & & & $23.9(16)$ & $18.2(2)$ & $1(1)$ & $5.3(19)$ \\
\hline
\end{tabular}

${ }^{a}$ numerous isolates encoded for more than one $\beta$-lactamase gene.

$b_{\%}$ of $\beta$-lactamase genes (no. of isolates). 
Figure 1). Among the human isolates $23 \%$ encoded CTX-M-1 and 52.5\% CTX-M-15. Some human isolates carried $b l a_{\mathrm{CTX}-\mathrm{M}-79}, b l a_{\mathrm{CTX}-\mathrm{M}-32}, b l a_{\mathrm{CTX}-\mathrm{M}-97}, b l a_{\mathrm{CTX}-\mathrm{M}-38}$ or bla $a_{\mathrm{CTX}-\mathrm{M}-117}$. The bla $a_{\mathrm{CTX}-\mathrm{M}-1}$ gene was found in $32.7 \%$ of human outpatient isolates and in $45.3 \%$ of inpatient isolates, while prevalence rates of $b l a_{\mathrm{CTX}-\mathrm{M}-15}$ were high and similar in both groups (outpatients 54.5\%, inpatients 51.6\%). Animal isolates revealed similar results as $28.7 \%$ of these isolates carried $b l a_{\mathrm{CTX}-\mathrm{M}-1}$ and $46.1 \%$ $b l a_{\mathrm{CTX}-\mathrm{M}-15}$. Other detected bla $a_{\mathrm{CTX}-\mathrm{M}}$ genes were bla $a_{\mathrm{CTX}-\mathrm{M}-2}, \quad b l a_{\mathrm{CTX-M-9}}, b l a_{\mathrm{CTX}-\mathrm{M}-97}, b l a_{\mathrm{CTX}-\mathrm{M}-79}$, and bla $a_{\mathrm{CTX}-\mathrm{M}-14}$. The presence of $b l a_{\mathrm{CTX}-\mathrm{M}-2,}$ bla $a_{\mathrm{CTX}-\mathrm{M}-9}$, and $b l a_{\mathrm{CTX}-\mathrm{M}-14}$ was restricted to animal isolates, while $b l a_{\mathrm{CTX}-\mathrm{M}-32}, b l a_{\mathrm{CTX}-\mathrm{M}-38}, b l a_{\mathrm{CTX}-\mathrm{M}-117}$ were found only among the human isolates. Bla $a_{\mathrm{CTX}-\mathrm{M}-1}$ was the dominant resistance subtype in horses (37\%) but it was less frequently isolated in dogs $(16.4 \%)$. In contrast, $b l a_{\text {CTX-M-15 }}$ occurred more often in dog isolates $(59.7 \%)$ than in isolates from horses $(38 \%)$ or cats $(36.4 \%)$. In addition, bla $a_{\text {CTX-M-15 }}$ was also the dominant CTX-M subtype among $K$. pneumoniae isolates whereas among the $E$. coli isolates both subtypes were present to the same degree. Altogether, $b l a_{\mathrm{CTX}-\mathrm{M}-1}$ and $b l a_{\mathrm{CTX}-\mathrm{M}-15}$ were the prominent $\beta$ lactamase genes present in $25.8 \%$ and $49.3 \%$ of all investigated isolates.

\section{TEM}

Non-ESBL gene $b l a_{\mathrm{TEM}-1}$ was the most frequently identified $\beta$-lactamase gene among all investigated isolates. It was detected in $46.4 \%$ of the human isolates and in $64 \%$ of all animal isolates. It was present in 199 of 361 isolates $(55 \%)$. The highest detection rates were observed in outpatients (58.2\%), inpatients (41.4\%), dog isolates $(62.7 \%)$ and horse isolates (67\%). TEM-52 was the only TEM-type ESBL that occurred in this study. It was identified in three isolates from human inpatients. Results are shown in Table 2.

\section{SHV}

Prevalence of bla $a_{\mathrm{SHV}}$ was $17.2 \%$ in human and $52.9 \%$ in animal K. pneumoniae. Bla $a_{\mathrm{SHV}-1}$ was identified in $10.3 \%$ of the human and in $29.4 \%$ of the animal K. pneumoniae isolates. Several ESBL variants could be identified in addition (Table 2). Most of the latter isolates originated from dogs. Detected SHV-type ESBL genes were $b l a_{\mathrm{SHV}-2}$, bla $a_{\mathrm{SHV}-5}, b l a_{\mathrm{SHV}-11}$ and bla $a_{\mathrm{SHV}-28}$. Bla $a_{\mathrm{SHV}-5}$ and $b l a_{\mathrm{SHV}-11}$ were restricted to isolates from human inpatients. ESBL genes $b l a_{\mathrm{SHV}-2}$ and $b l a_{\mathrm{SHV}-28}$ were detected among the animal isolates only.

\section{OXA-1}

The presence of the penicillinase gene $b l a_{\text {OXA-1 }}$ could be demonstrated in $30.1 \%$ of the human isolates. Among the animal isolates $b l a_{\mathrm{OXA}-1}$ was identified in $41.6 \%$ of all strains. Detection rates were highest in isolates from dogs $(59.7 \%)$, followed by cat (45.5\%), outpatient (32.8\%) and horse $(29 \%)$ isolates. However, bla $a_{\text {OXA-1 }}$ was also found in inpatient isolates (23.6\%) (Table 2).

\section{OXA-48}

All carbapenem resistant isolates (human isolates: 45, animal isolates: 40) were tested for presence of the carbapenemase OXA-48. None of the tested human isolates

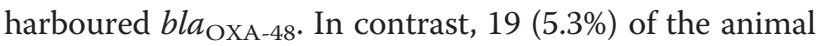
isolates harboured this gene. The isolates harbouring bla $a_{\text {OXA-48 }}$ originated from dogs (16), cats (2) and a horse (Table 2).

\section{PMQR}

Distribution and presence of PMQR genes are illustrated in Table 3. The most frequently detected PMQR gene in ciprofloxacin-resistant isolates $(\mathrm{n}=262)$ was $a a c($ '6) $-\mathrm{Ib}$ cr. Prevalence was $27.9 \%(\mathrm{n}=39)$ in the human isolates, $36.9 \%(n=45)$ in the animal isolates and $32.1 \%(n=84)$ in all investigated isolates. None of the isolates carried $q n r C$ or $q e p A$. Among the human isolates $q n r B$ was found in three and $q n r S$ in five isolates. Two more $q n r$ variants were detected among the animal isolates. Gene $q n r A$ was carried by three, $q \eta r B$ by seven, $q n r D$ by eight and $q n r S$ by five animal isolates. Most $q n r$ type genes ( $q n r A, q n r B, q n r D, q n r S)$ were detected in $\operatorname{dog}$ isolates. Inpatient isolates carried PMQR genes at higher rates (37.8\%) than isolates from outpatients (23.8\%). A similar observation could be made among the animal isolates. Highest identification rates (49.5\%) were observed in isolates originating from animals tested during stay in the small animal clinic. In summary, most PMQR genes were present in dog isolates (65.1\%). Overall, PMQR genes could be demonstrated in $43.9 \%(n=115)$ of all investigated isolates.

\section{Analysis of resistance gene patterns}

Preliminary detection and visualization of clusters and/ or resistance patterns in context to isolate source and bacterial species was performed using Figure 1 which was generated by means of the GENE-E program. Data was then confirmed by analysis of absolute and relative numbers/ percentages as displayed in Table 4. Combinations of various plasmid encoded resistance genes (ESBL and non-ESBL $\beta$-lactamases and PMQR) were observed in the majority of isolates $(70.1 \%)$ included in this study (Table 4 and Figure 1). Most frequently detected (26.3\%) was the combination of a TEM type penicillinase with a CTX-M type ESBL. Also regularly observed was a penicillinase (TEM or OXA-1) in combination with CTX-M and plasmid-mediated quinolone resistance (PMQR) genes. These combinations were predominantly found among E. coli isolates. Other isolates encoded for 


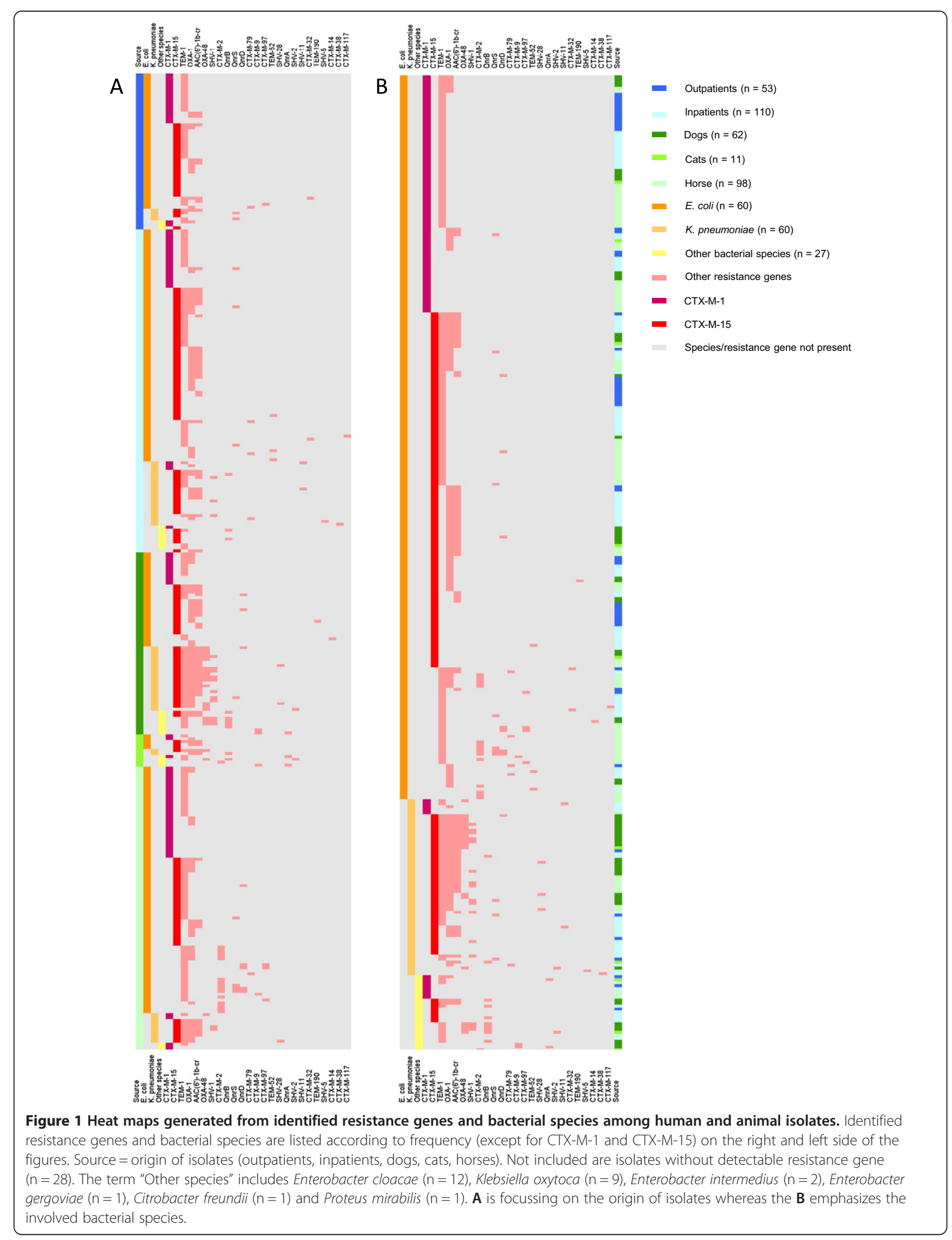


Table 3 Distribution of PMQR genes in ciprofloxacin-resistant isolates $(n=262)$ of human and animal origin

\begin{tabular}{|c|c|c|c|c|c|c|c|c|}
\hline \multirow[b]{2}{*}{ Source } & \multirow[b]{2}{*}{ No. of isolates ${ }^{b}$} & \multicolumn{7}{|c|}{$\%$ of PMQR genes (no. of isolates) } \\
\hline & & qnrA & qnrB & qnrC & qnrD & qnrS & qepA & $a a c\left(6^{\prime}\right)-I b-c r$ \\
\hline \multicolumn{9}{|l|}{ Human } \\
\hline Outpatients & 42 & & & & & $4.8(2)$ & & $19(8)$ \\
\hline Inpatients & 98 & & $3.1(3)$ & & & $3.1(3)$ & & $31.6(31)$ \\
\hline Total & 140 & & $2.1(3)$ & & & $3.6(5)$ & & $27.9(39)$ \\
\hline \multicolumn{9}{|l|}{ Animal } \\
\hline Dogs & 63 & $1.6(1)$ & $7.9(5)$ & & $4.8(3)$ & $1.6(1)$ & & $49.2(31)$ \\
\hline Cats & 10 & $20(2)$ & $20(2)$ & & & & & $40(4)$ \\
\hline Horses & 49 & & & & $10.2(5)$ & $8.2(4)$ & & $20.4(10)$ \\
\hline Total & 122 & $2.5(3)$ & $5.7(7)$ & & $6.6(8)$ & $4.1(5)$ & & $36.9(45)$ \\
\hline Total no. of isolates & 262 & $1.1(3)$ & $3.8(10)$ & & $3.1(8)$ & $3.8(10)$ & & $32.1(84)$ \\
\hline
\end{tabular}

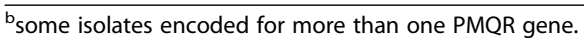

several combinations of a TEM penicillinase, CTX-M enzymes, the penicillinase $b l a_{\mathrm{OXA}-1}$, the penicillinase $b l a_{\mathrm{SHV}}$ and PMQR genes. The carbapenemase OXA-48 was mainly associated with numerous resistance genes such as a TEM penicillinase, CTX-M and PMQR. In addition, it was exclusively identified in $K$. pneumoniae and Enterobacter cloacae isolates from animals. Another frequently observed combination was that of bla $a_{\text {CTX-M- }}$ 15 and $a a c(' 6)-I b-c r$. Other combinations were detected only once or to a much lesser extent than those mentioned above. Combination of more than two resistance genes could be observed more often among human $E$. coli isolates and especially among $K$. pneumoniae animal isolates (Figure 1).

\section{Phylogenetic grouping of $\beta$-lactamase-producing $E$. coli}

Phylogenetic group typing was applied to 141 human and 126 animal ESBL-producing E. coli isolates (Table 5 and Figure 2). Both groups differed from each other in the frequencies of known phylogenetic groups. In general, the human isolates were almost evenly distributed among the phylogenetic groups A (30.5\%), B1 (27.7\%) and B2 (26.2\%) and to a lesser extent with group D (15.6\%). In contrast, most of the analysed animal isolates belonged to group A (43.7\%) and a considerably smaller number of isolates to B1 (35.7\%). Approximately $17.5 \%$ of all animal isolates could be assigned to group D, whereas only $2.4 \%$ were classified as group B2.

\section{Discussion}

The global spread of multi-resistant ESBL-producing Enterobacteriaceae can in part be explained by mobility of the resistance bearing genetic elements e.g. plasmids, transposons and insertion sequence elements. This fact is a major concern in terms of epidemiology and infection control. Transmission pathways between humans and animals are currently a subject of active discussion
$[8,24,25]$. This study was designed to investigate the distribution of $\beta$-lactamases, particularly ESBL, and PMQR genes among isolates from human, companion animal and horse samples in a defined geographical area of Germany. The key question was whether similar resistance characteristics are currently present among both groups. Indeed, our studies here demonstrate that isolates from human and animal samples share numerous characteristics.

Antimicrobial susceptibility testing revealed common and disturbing patterns. High resistance rates for all $\beta$ lactams and other antibiotic classes were observed. In particular animal isolates harbouring resistance to the last-resort antibiotics ertapenem and impenem were detected. The results for ertapenem were particularly alarming, with $16.3 \%$ resistance among animal isolates and $24 \%$ among the human isolates. In Germany, the use of carbapenems in livestock animals is prohibited and its use for treating companion animals is strongly restricted. Nevertheless, almost all ertapenem resistant strains among the animal isolates (95.6\%) originated from dogs and cats. This would suggest human to animal transmission of resistant strains by their owners. Alternatively, the use of carbapenems for treatment of companion animals cannot be excluded even though these pharmaceuticals are expensive and their use is uncommon even in pet animal practice. Carbapenemase activity in bacteria from companion animals and livestock has been already identified recently [26-28]. To investigate this phenomenon in more detail, all carbapenem resistant isolates from this study were tested for the presence of $b l a_{\text {OXA-48. }}$. Surprisingly, a substantial difference could be observed regarding the molecular mechanisms underlying this resistance phenotype. None of the 45 tested human isolates was positive for $b l a_{\text {OXA-48 }}$, though 26 (57.8\%) were identified with a possible combination of an AmpC enzyme and porin deficiency. This mechanism has been observed previously in AmpC-producing K. pneumoniae by Shi et al. They stated 
Table 4 Observed combinations of $\beta$-lactamase and PMQR genes according to bacterial species

\begin{tabular}{|c|c|c|c|c|c|c|c|c|c|c|c|c|c|c|c|c|c|c|c|c|c|c|c|}
\hline \multirow{3}{*}{$\begin{array}{l}\text { Combination of } \\
\text { resistance genes }^{\mathrm{a}}\end{array}$} & \multicolumn{4}{|c|}{ Outpatients } & \multicolumn{5}{|c|}{ Inpatients } & \multicolumn{5}{|c|}{ Dogs } & \multicolumn{5}{|c|}{ Cats } & \multicolumn{4}{|c|}{ Horses } \\
\hline & \multicolumn{23}{|c|}{$\%$ of bacterial species (no. of isolates) } \\
\hline & $E C$ & KP & KO & $E N O S^{b}$ & $E C$ & $K P$ & KO & $E N$ & $O S^{b}$ & $E C$ & $K P$ & KO & $E N$ & $O S^{b}$ & $E C$ & $K P$ & KO & $E N$ & $O S^{b}$ & $E C$ & $K P$ & KO EN & $O S^{b}$ \\
\hline $\mathrm{TEM}_{\text {Pen }} / \mathrm{CTX}-\mathrm{M}$ & $50(24)$ & & & & $26.9(25)$ & $12(3)$ & & & & $17.1(6)$ & & & & & $20(1)$ & & & & & $40.7(35)$ & & & $25(1)$ \\
\hline $\begin{array}{l}\text { TEM } \\
\text { PMQn } / C T X-M / \\
\text { PMQR }\end{array}$ & & $25(1)$ & & & $1.2(1)$ & & & $25(1)$ & & $2.9(1)$ & & & & & $20(1)$ & & & $33.3(1)$ & & $8.1(7)$ & & & \\
\hline $\begin{array}{l}\text { TEM }_{\text {Pen }} / \text { CTX-M/ } \\
\text { OXA }_{\text {Pen }}\end{array}$ & $2.1(1)$ & & $33.3(1)$ & & $2.2(2)$ & & & & & $14.3(5)$ & & & & & & & & & & $12.8(11)$ & $10(1)$ & & \\
\hline $\begin{array}{l}\text { TEM }_{\text {Pen }} / \text { CTX-M/ } / \\
\text { OXA }_{\text {Pen }} / \text { PMQR }\end{array}$ & $4.2(2)$ & $25(1)$ & & & $8.6(8)$ & $8(2)$ & & & & $8.6(3)$ & $18.2(4)$ & $100(1)$ & $12.5(1)$ & & $20(1)$ & & & & & $1.2(1)$ & $40(4)$ & & \\
\hline $\begin{array}{l}\mathrm{TEM}_{\mathrm{Pen}} / \mathrm{SHV}_{\mathrm{Pen}} / \\
\text { CTX-M/OXA } / \\
\text { PMQR }\end{array}$ & & & & & & $4(1)$ & & & & & $9.1(2)$ & & & & & & & & & & $20(2)$ & & \\
\hline 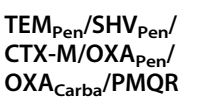 & & & & & & & & & & & $22.7(5)$ & & & & & & & & & & & & \\
\hline $\begin{array}{l}\text {TEM }_{\text {Pen }} / \text { CTX-M/ } \\
\text { OXA }_{\text {Pen }} / \text { OXA }_{\text {Carba }} / \\
\text { PMQR }\end{array}$ & & & & & & & & & & & $27.3(6)$ & & & & & $50(1)$ & & & & & & & \\
\hline $\begin{array}{l}\text { CTX-M/OXA }{ }_{\text {Pen }} / \\
\text { PMQR }\end{array}$ & $8.3(4)$ & & & & $14(13)$ & $12(3)$ & & & & $17.1(6)$ & & & & & $20(1)$ & & & & & $3.5(3)$ & & & \\
\hline $\begin{array}{l}\mathrm{TEM}_{\text {Pen }} / \mathrm{SHV}_{\mathrm{Pen}} / \\
\mathrm{OXA}_{\text {Carba }} / \mathrm{PMQR}\end{array}$ & & & & & & & & & & & & & $37.5(3)$ & & & & & & & & & & \\
\hline CTX-M/PMQR & & & & & $2.2(2)$ & & $20(1)$ & & & $5.7(2)$ & & & $12.5(1)$ & & & & & $33.3(1)$ & & & & & \\
\hline CTX-M/OXA Pen & $8.3(4)$ & & & & $6.5(6)$ & $8(2)$ & & & & $2.9(1)$ & & & & & $20(1)$ & & & & & $8.1(7)$ & & & \\
\hline $\begin{array}{l}\text { Other } \\
\text { combinations }\end{array}$ & $2.1(1)$ & $25(1)$ & & & $3.2(3)$ & $16(4)$ & & & & & $22.7(5)$ & & $12.5(1)$ & & & $50(1)$ & & $33.3(1)$ & & & $20(2)$ & & \\
\hline $\begin{array}{l}\text { No resistance } \\
\text { gene detected }\end{array}$ & $4.2(2)$ & & & & $14(13)$ & $12(3)$ & & $50(2)$ & & $8.6(3)$ & & & $12.5(1)$ & $100(1)$ & & & & & & $2.3(2)$ & & & \\
\hline Single resistance & $20.8(10)$ & $25(1)$ & $66.7(2)$ & & $21.5(20)$ & $28(7)$ & $80(4)$ & $25(1)$ & $100(1)$ & $22.9(8)$ & & & $12.5(1)$ & & $20(1)$ & & & & 1 & $23.3(20)$ & $10(1)$ & & $75(3)$ \\
\hline
\end{tabular}

$\begin{array}{llllllllllllllllllllllllllllllllllll}\text { Total no. of } & 48 & 4 & 3 & 0 & 0 & 93 & 25 & 5 & 4 & 1 & 35 & 22 & 1 & 8 & 1 & 5 & 2 & 0 & 3 & 1 & 86 & 10 & 0 & 0 & 4\end{array}$ isolates

$E C$, Escherichia coli; KP, Klebsiella pneumoniae; KO, Klebsiella oxytoca; EN, Enterobacter cloacae; OS, Other species.

${ }^{\mathrm{a}} \mathrm{TEM}$ Pen, TEM Penicillinase, OXA Pen, OXA Pencillinase, OXA Carbar OXA Carbapenemase, SHV

${ }^{b}$ Other species include Enterobacter intermedius $(n=2)$. Enterobacter gergoviae $(n=1)$, Citrobacter freundii $(n=1)$, and Proteus mirabilis $(n=1)$, Providencia stuartii $(n=1)$, Morganella morganii $(n=1)$. 
Table 5 Distribution of $E$. coli phylogenetic groups among human and animal isolates $(\mathbf{n}=267)$

\begin{tabular}{|c|c|c|c|c|c|}
\hline \multirow[b]{2}{*}{ Source } & \multirow[b]{2}{*}{ No. of isolates } & \multicolumn{4}{|c|}{$\%$ of phylogenetic groups (no. of isolates) } \\
\hline & & A & B1 & B2 & D \\
\hline \multicolumn{6}{|l|}{ Human } \\
\hline Outpatients & 48 & $31.3(15)$ & $29.2(14)$ & $25(12)$ & $14.6(7)$ \\
\hline Inpatients & 93 & $30.1(28)$ & $26.9(25)$ & $26.9(25)$ & $16.1(15)$ \\
\hline Total & 141 & $30.5(43)$ & $27.7(39)$ & $26.2(37)$ & $15.6(22)$ \\
\hline \multicolumn{6}{|l|}{ Animal } \\
\hline Dogs & 35 & $48.6(17)$ & $22.9(8)$ & $2.9(1)$ & $25.7(9)$ \\
\hline Cats & 5 & $60(3)$ & $20(1)$ & & $20(1)$ \\
\hline Horses & 86 & $40.7(35)$ & $41.9(36)$ & $2.3(2)$ & $14(12)$ \\
\hline Total & 126 & $43.7(55)$ & $35.7(45)$ & $2.4(3)$ & $17.5(22)$ \\
\hline Total no. of isolates & 267 & 36.7 (98) & $31.5(84)$ & $14.9(40)$ & $16.5(44)$ \\
\hline
\end{tabular}

that the combination of AmpC production and porin loss can result in reduced susceptibility to carbapenems [29]. In contrast to these results, 19 (47.5\%) of the 40 examined animal isolates harboured an OXA-48 carbapenemase.

Among 361 isolates resistant to one or more third generation cephalosporins $84 \%$ harboured a CTX-M type enzyme. Predominant ESBL genes in human and animal samples were $b l a_{\mathrm{CTX}-\mathrm{M}-15}$ and $b l a_{\mathrm{CTX}-\mathrm{M}-1}$. In the past bla $a_{\mathrm{CTX}-\mathrm{M}-15}$ was merely associated with isolates from humans [30] and CTX-M-1 was the major CTX-M subtype in cattle and pigs in Europe [31]. In addition bla $_{\text {CTX-M-1 }}$ was also detected in companion animal and poultry isolates [32,33]. In the meantime, attribution of the above-named CTX-M types as specific to either

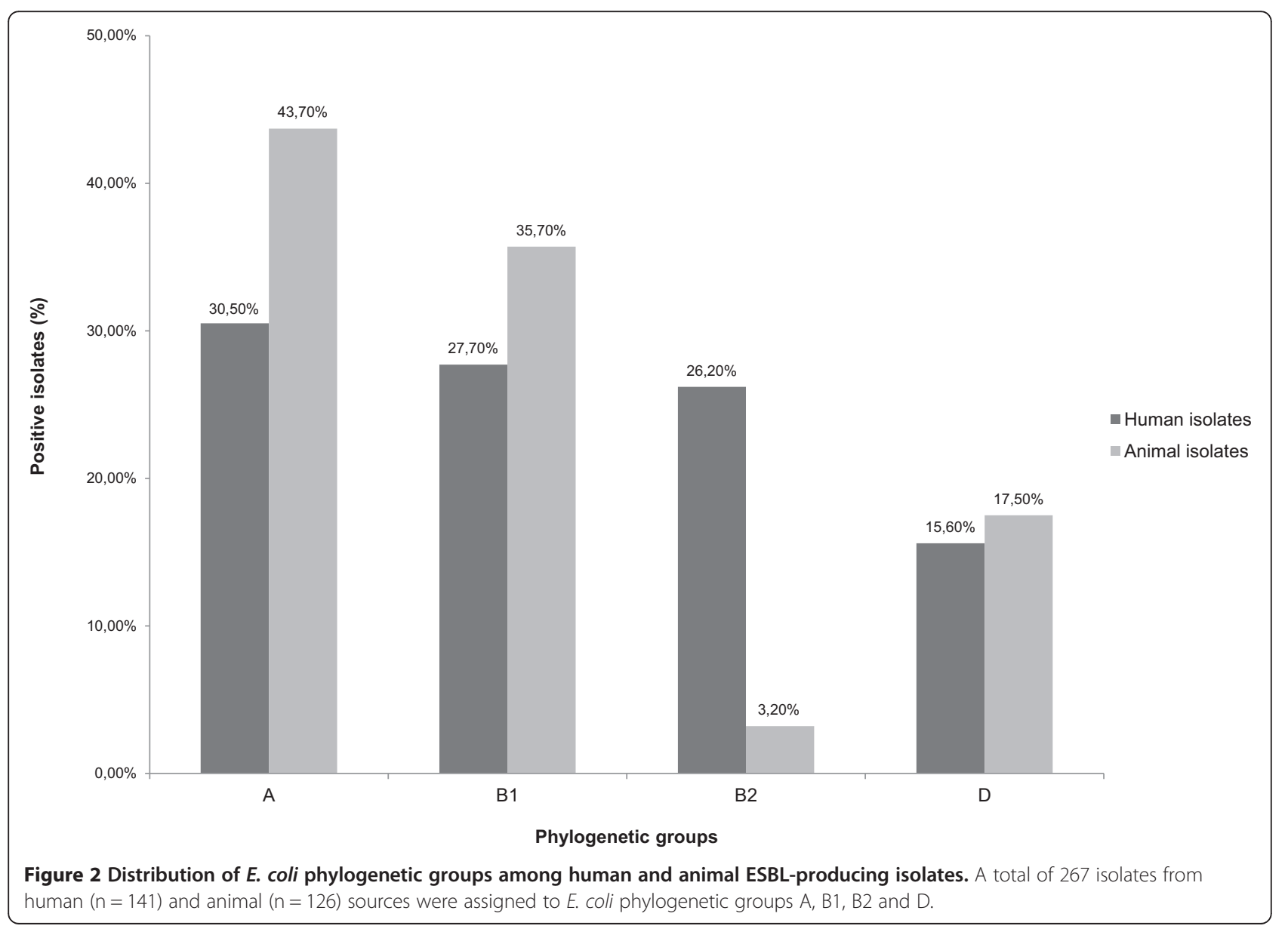


human or animal isolates is no longer tenable. An increasing number of studies have identified $b l a_{\text {СтХ-M-1 }}$ and $b l a_{\mathrm{CTX}-\mathrm{M}-15}$ in both populations [3,34] and our study confirmed this development. Among our isolates bla $a_{\mathrm{CTX}-\mathrm{M}-15}$ was the most prevalent ESBL gene which occurred in approximately $50 \%$ of the strains investigated (human: $52.5 \%$, animal: $46.1 \%$ ). The number for bla $a_{\text {СтХ-M-1 }}$ was considerably lesser but this gene was still relatively frequently present $(23 \%, 28.7 \%)$. Isolates collected from horses seemed to hold a special position since rates of $b l a_{\mathrm{CTX}-\mathrm{M}-1^{-}}$and $b l a_{\mathrm{CTX}-\mathrm{M}-15}$-positive isolates were almost equal (bla $a_{\mathrm{CTX}-\mathrm{M}-1} 37 \%$; $b l a_{\mathrm{CTX}-\mathrm{M}-15}$ 38\%). Previous studies have mainly identified CTX-M-1 as the predominant ESBL subtype among horse isolates $[35,36]$, which is also the most common type among livestock. In Germany horses are mostly used as recreational animals, normally situated close to livestock or in livestock-like environments. However, they usually have closer contact to humans and in case of disease medical care for horses is much more intense than in agricultural animal species. This could be a possible explanation for the particularly high detection rates of $b l a_{\mathrm{CTX}-\mathrm{M}-15}$ reported here. Interestingly, $b l a_{\mathrm{CTX} \text {-M-2 }}$ was found almost exclusively in equine $E$. coli isolates and was not present among human isolates. A study from Belgium identified $b l a_{\mathrm{CTX}-\mathrm{M}-2}$ as major CTX-M subtype among diseased horses [37]. These animals had received prolonged treatment with several antibiotics and the $b l a_{\mathrm{CTX}-\mathrm{M}-2}$ gene was part of the novel complex class 1 integron ISCR $R_{1}$. Ferreira et al. could demonstrate the same linkage between $b l a_{\mathrm{CTX}-\mathrm{M}-2}$ and ISCR $R_{1}$ however, within the chromosome of $E$. coli isolates from healthy broiler chickens in Brazil [38]. Further investigation of the region surrounding the $b l a_{\mathrm{CTX}-\mathrm{M}-2}$ gene may be necessary to identify possible associations with $I S C R_{1}$ among the isolates examined in this work. However, the CTX-M2 subtype is not restricted to animal or even horse isolates. It was previously found in Salmonella enterica isolates from the UK and E. coli isolates from Brazil originating from clinically ill human patients $[39,40]$.

Ciprofloxacin-resistant animal isolates (55.7\%) showed higher prevalence of PMQR-encoding genes compared to human isolates (33.6\%). In addition, four qnr-variants ( $q n r A, q n r B$, qnrD and $q n r S$ ) were identified in the group of animal isolates, compared to only $q n r B$ and $q n r S$ among the human isolates. All identified $q n r$ variants have already been identified in both groups, however no study is consistent with the results found here [41,42].

Another interesting result is the low prevalence of $b l a_{\mathrm{SHV}-1}$ among the $K$. pneumoniae isolates $(10.3 \%$ of the human and in $29.4 \%$ of the animal K. pneumoniae isolates). Even though it is widely considered a plasmidencoded enzyme, it has been found at high frequencies in K. pneumoniae. Further the $b l a_{\mathrm{SHV}-1}$ origin is suspected in the chromosome of K. pneumoniae [43]. As some authors indicate high frequencies of up to $90 \%$ in K. pneumoniae isolates, our data does not seem to fit into the picture [43]. Yet there are other studies showing also low prevalences [44]. Based on these data it could be a local phenomenon.

The $\beta$-lactamase genes $b l a_{\mathrm{SHV}-1}, b l a_{\mathrm{SHV}-5}, b l a_{\mathrm{SHV}-11}$ and bla $a_{\text {TEM-52 }}$ were restricted to isolates from inpatients. This fact could be explained by their ancestry, since these genes are frequently found in isolates from hospitals [45].

Combination of various resistance genes was the rule rather than the exception (Table 4). In $70.1 \%$ of all isolates two or more genes responsible for $\beta$-lactam or quinolone resistance were identified. Combinations of several $\beta$-lactamase genes are commonly observed regularly within genomes of Gram-negative bacterial pathogens $[46,47]$ and co-selection of $\beta$-lactamase genes and determinants for resistance against other antibiotics e.g. fluoroquinolones has been postulated as a possible mechanism responsible for the widespread distribution of those combined genes [48]. The frequently observed combination of bla $a_{\mathrm{CTX}-\mathrm{M}-15}$ and $a a c($ ' 6 )-Ib-cr could provide genetic support for this theory, which has been noted before $[49,50]$. For this study the presence of bla $a_{\text {OXA }-48}$ in combination with at least two penicillinase genes e.g. TEM, SHV or OXA, a PMQR gene and even sometimes with a CTX-M gene is alarming. Even more worrying is the fact that almost all isolates identified with the OXA-48 carbapenemase originate from companion animals. However, other carbapenemases could be present among the human and animal isolates, which were not tested for. The carbapenem-resistant animal isolates were mainly $K$. pneumoniae and Enterobacter cloacae isolates. An unrelated study conducted in our geographic region also detected carbapenem-resistant Klebsiella spp. among isolates from dogs [26].

E. coli and K. pneumoniae are the main species associated with $\beta$-lactamase production among isolates resistant to third generation cephalosporins in Germany and other members of the European Union [51]. Data from this study underlines this predominance of both bacterial species as a carrier of ESBL-encoding resistance genes with $74 \%$ E. coli and $17.5 \% \mathrm{~K}$. pneumoniae isolates in total. Interestingly, the phylogenetic group B2 was strongly underrepresented among the ESBL-E. coli isolates from animals. Compared to the human isolates $(26.2 \%)$ it was only present in $2.4 \%$. The origins of primary sample material could provide an explanation for this discrepancy. Several studies suggest dominance of certain phylogenetic groups in particular specimen and types of infection $[52,53]$. Zhang et al. demonstrated clustering of phylogenetic group $\mathrm{B} 2$ among urinary $E$. coli isolates from human patients [52]. The fact that $53 \%$ of the human 
isolates in this study had been recovered from urine while only $19 \%$ were from rectal swabs suggests an association between higher numbers of B2-E. coli isolates and the urinary tract of humans. The main source for the animal isolates was faeces (51\%) from animals suffering from enteritis, diarrhoea and colic. It is not known whether the ESBL isolates detected were indeed causative for the syndromes observed as they could also be commensal strains that were selectively isolated solely on the basis of their resistance phenotype. This could explain the strong presence of phylogenetic group A/B1 and almost complete lack of group B2. Nevertheless, the pathogenic potential of ESBL-encoding isolates remains uncertain and needs further research. Studies performed on $E$. coli harbouring $\beta$-lactamases revealed several virulence-associated traits such as toxins, fimbriae, siderophores, polysaccharide coatings and invasins [54,55]. In addition, patients with bacteremic urinary tract infections (UTIs) caused by ESBL-producing Enterobacteriaceae also have prolonged hospitalization and higher antibiotic costs [56].

Our study has limitations with regard to the selection of isolates. Human isolates originate from screening of patients upon admission for carrier-status as well as from clinically ill patients, whereas animal isolates only derive from diseased animals. In addition, selection criteria for ESBL- or PMQR-carrying isolates might have introduced bias. A screening breakpoint of $>1 \mathrm{mg} / \mathrm{L}$ is recommended for cefotaxime in accordance with the guidelines issued by EUCAST [9]. Usage of the higher concentration of $2 \mathrm{mg} /$ L might have led to loss of some ESBL types. PMQRgenes typically induce low-level quinolone-resistance with ciprofloxacin MIC of $\geq 0.25 \mu \mathrm{g} / \mathrm{mL}$ [57]. For this reason some PMQR may not have been detected due to the MIC of $1 \mu \mathrm{g} / \mathrm{mL}$ used.

Notwithstanding, the study gives an overall view on current dissemination of ESBL-encoding Enterobacteriaceae isolates within the region investigated. Further studies should be directed to examining specific transmission pathways assessing the exchange between the human and animal populations in owner-pet studies. In order to address this aspect in more detail, simultaneous screening of pets and/or owners positive for ESBL-producing Enterobacteriaceae should be carried out in the future. Another important factor for possible transmission or spread is the environment. Multiresistant bacteria are isolated with increasing frequencies from soil or water and wildlife [58]. Some studies implicate ESBL-producing E. coli already as a form of environmental pollution [59]. Our findings are supported by other non-regional studies that confirm the data presented $[4,60,61]$. In line with this work several studies describe presence of ESBL producing Enterobacteriaceae among human and animal samples with dominance of the CTX-M subtype [1-3].
Other aspects such as the colonisation and persistence in humans, animals and the environment as well as host species adaption and interspecies transmissibility of the bacteria involved must be taken into account. As plasmids are epidemiologically relevant agents in ESBL transfer, their role and association with sequence types (STs) need to be examined. Transfer of similar plasmids from human to animal bacterial populations and vice versa has been shown in broilers and broiler farmers in the Netherlands [62] and suggest that a similar situation could also exist between pet and owner.

\section{Conclusions}

The results from this study substantiate the alarming occurrence and ongoing spread of various ESBL-producing, multiresistant Enterobacteriaceae strains in the human and animal populations within a defined geographic region in central Hesse, Germany. Our data confirm that companion animals represent novel reservoirs of carbapenemaseproducing strains of $K$. pneumoniae and Enterobacter cloacae. The study strongly supports the One Health concept which expands interdisciplinary collaborations and communications in all aspects pertaining to the health care for humans and animals [63].

\section{Ethical approval}

The study was approved by the ethics committee of medical faculty of the Justus Liebig University of Giessen (AZ: 95/11).

\section{Competing interests}

The authors declare that they have no competing interests.

\section{Authors' contributions}

$\mathrm{Cl}, \mathrm{RB}, \mathrm{ED}$ and TC designed the study, JS and LF performed the experiments, JS, LF, Cl, RB and TC analysed the data, JS, LF, Cl, RB, ED and TC wrote the manuscript which was corrected and approved by all the other co-authors.

\section{Acknowledgements}

We thank Christina Gerstmann, Anja Schwanitz and David Dippel for excellent technical assistance.

This study was supported by grants from the Federal Ministry of Education and Research (BMBF, Germany) within the framework of the RESET research network (contract no. 01Kl1013G) and the German Centre for Infection research (DZIF / grant number 8000 701-3 [HZI]) to TC and Cl.

\section{Author details}

${ }^{1}$ Institute of Medical Microbiology, Justus Liebig University Giessen and German Center for Infection Research (DZIF), Partner site Giessen-Marburg-Langen, Schubertstrasse 81, 35392 Giessen, Germany. ${ }^{2}$ Institute of Hygiene and Infectious Diseases of Animals, Justus Liebig University Giessen, Frankfurter Strasse 85-89, 35392 Giessen, Germany.

Received: 23 April 2014 Accepted: 7 July 2014

Published: 12 July 2014

\section{References}

1. Liebana E, Carattoli A, Coque TM, Hasman H, Magiorakos AP, Mevius D, Peixe L, Poirel L, Schuepbach-Regula G, Torneke K, Torren-Edo J, Torres C, Threlfall J: Public health risks of enterobacterial isolates producing extended-spectrum-lactamases or AmpC-lactamases in food and food-producing animals: An EU perspective of epidemiology, analytical 
methods, risk factors, and control options. Clin Infect Dis 2013, 56:1030-1037.

2. Dolejska M, Villa L, Hasman H, Hansen L, Carattoli A: Characterization of IncN plasmids carrying blaCTX-M-1 and qur genes in Escherichia coli and Salmonella from animals, the environment and humans. J Antimicrob Chemother 2013, 68:333-339.

3. Ewers C, Bethe A, Semmler T, Guenther S, Wieler LH: Extended-spectrum $\beta$-lactamase-producing and $\mathrm{AmpC}$-producing Escherichia coli from livestock and companion animals, and their putative impact on public health: a global perspective. Clin Microbiol Infect 2012, 18:646-655.

4. Wu G, Day MJ, Mafura MT, Nunez-Garcia J, Fenner JJ, Sharma M, van Essen-Zandbergen A, Rodríguez I, Dierikx C, Kadlec K: Comparative analysis of ESBL-positive Escherichia coli isolates from animals and humans from the UK, the Netherlands and Germany. PLoS One 2013, 8:e75392.

5. Ewers C, Grobbel M, Stamm I, Kopp PA, Diehl I, Semmler T, Fruth A Beutlich J, Guerra B, Wieler LH, Guenther S: Emergence of human pandemic 025:H4-ST131 CTX-M-15 extended-spectrum- $\beta$-lactamaseproducing Escherichia coli among companion animals. J Antimicrob Chemother 2010, 65:651-660.

6. Ewers C, Bethe A, Stamm I, Grobbel M, Kopp PA, Guerra B, Stubbe M, Doi Y, Zong Z, Kola A, Schaufler K, Semmler T, Fruth A, Wieler LH, Guenther S: CTX-M-15-D-ST648 Escherichia coli from companion animals and horses: another pandemic clone combining multiresistance and extraintestinal virulence? J Antimicrob Chemother 2014, 69:1224-1230.

7. Friese A, Schulz J, Laube H, von Salivati C, Hartung J, Roesler U: Faecal occurrence and emissions of livestock-associated methicillin-resistant Staphylococcus aureus (laMRSA) and ESBL/AmpC-producing E. coli from animal farms in Germany. Berl Munch Tierarztl Wochenschr 2013, 126:175-180.

8. Meyer E, Gastmeier P, Kola A, Schwab F: Pet animals and foreign travel are risk factors for colonisation with extended-spectrum $\beta$-lactamaseproducing Escherichia coli. Infection 2012, 40:685-687.

9. EUCAST: 2012 EUCAST guidelines for detection of resistance mechanisms and specific resistances of clinical and/or epidemiological importance. [http://www.eucast.org/fileadmin/src/media/PDFs/EUCAST_files/Consultation /EUCAST_guidelines_detection_of_resistance_mechanisms_121222.pdf]

10. Mshana SE, Imirzalioglu C, Hossain H, Hain T, Domann E, Chakraborty T: Conjugative IncFI plasmids carrying CTX-M-15 among Escherichia coli ESBL producing isolates at a university hospital in Germany. BMC Infect Dis 2009, 9:97.

11. Grobner S, Linke D, Schutz W, Fladerer C, Madlung J, Autenrieth IB, Witte W, Pfeifer $Y$ : Emergence of carbapenem-non-susceptible extended-spectrum beta-lactamase-producing Klebsiella pneumoniae isolates at the university hospital of Tubingen, Germany. J Med Microbiol 2009, 58:912-922.

12. Kiratisin P, Apisarnthanarak A, Laesripa C, Saifon P: Molecular characterization and epidemiology of extended-spectrum- $\beta$-lactamaseproducing Escherichia coli and Klebsiella pneumoniae isolates causing health care-associated infection in Thailand, where the CTX-M family is endemic. Antimicrob Agents Chemother 2008, 52:2818-2824.

13. Castillo B, Vinué L, Román EJ, Guerra B, Carattoli A, Torres C, MartínezMartínez L: Molecular characterization of multiresistant Escherichia coli producing or not extended-spectrum $\beta$-lactamases. BMC Microbiol 2013, 13:84.

14. Chen X, Zhang W, Pan W, Yin J, Pan Z, Gao S, Jiao X: Prevalence of qnr, $\operatorname{aac}\left(6^{\prime}\right)-\mathrm{lb}-\mathrm{cr}$, qepA, and oqxAB in Escherichia coli Isolates from humans, animals, and the environment. Antimicrob Agents Chemother 2012, 56:3423-3427

15. Cattoir V, Poirel L, Nordmann P: Plasmid-mediated quinolone resistance pump QepA2 in an Escherichia coli isolate from France. Antimicrob Agents Chemother 2008, 52:3801-3804.

16. Cattoir V, Poirel L, Rotimi V, Soussy CJ, Nordmann P: Multiplex PCR for detection of plasmid-mediated quinolone resistance qnr genes in ESBL-producing enterobacterial isolates. J Antimicrob Chemother 2007, 60:394-397

17. Wang M, Guo Q, Xu X, Wang X, Ye X, Wu S, Hooper DC: New plasmidmediated quinolone resistance gene, qnrC, found in a clinical isolate of Proteus mirabilis. Antimicrob Agents Chemother 2009, 53:1892-1897.

18. Cavaco LM, Hasman H, Xia S, Aarestrup FM: qnrD, a novel gene conferring transferable quinolone Resistance in Salmonella enterica serovar Kentucky and Bovis morbificans strains of human origin. Antimicrob Agents Chemother 2009, 53:603-608.
19. Park $\mathrm{CH}$, Robicsek A, Jacoby GA, Sahm D, Hooper DC: Prevalence in the United States of aac $\left(6^{\prime}\right)-\mathrm{lb}-\mathrm{cr}$ encoding a ciprofloxacin-modifying enzyme. Antimicrob Agents Chemother 2006, 50:3953-3955.

20. Jones GL, Warren RE, Skidmore SJ, Davies VA, Gibreel T, Upton M: Prevalence and distribution of plasmid-mediated quinolone resistance genes in clinical isolates of Escherichia coli lacking extended-spectrum beta-lactamases. J Antimicrob Chemother 2008, 62:1245-1251.

21. Clermont O, Bonacorsi S, Bingen E: Rapid and simple determination of the Escherichia coli phylogenetic group. Appl Environ Microbiol 2000, 66:4555-4558

22. GENE-E. [http://www.broadinstitute.org/cancer/software/GENE-E/]

23. Magiorakos AP, Srinivasan A, Carey RB, Carmeli Y, Falagas ME, Giske CG, Harbarth S, Hindler JF, Kahlmeter G, Olsson-Liljequist B, Paterson DL, Rice LB, Stelling J, Struelens MJ, Vatopoulos A, Weber JT, Monnet DL: Multidrugresistant, extensively drug-resistant and pandrug-resistant bacteria: An international expert proposal for interim standard definitions for acquired resistance. Clin Microbiol Infect 2012, 18:268-281.

24. Wieler LH, Ewers C, Guenther S, Walther B, Lübke-Becker A: Methicillinresistant staphylococci (MRS) and extended-spectrum beta-lactamases (ESBL)-producing Enterobacteriaceae in companion animals: Nosocomial infections as one reason for the rising prevalence of these potential zoonotic pathogens in clinical samples. Int J Med Microbiol 2011 301:635-641.

25. Rodriguez I, Barownick W, Helmuth R, Mendoza MC, Rodicio MR, Schroeter A, Guerra B: Extended-spectrum $\beta$-lactamases and AmpC $\beta$-lactamases in ceftiofur-resistant Salmonella enterica isolates from food and livestock obtained in Germany during 2003-07. J Antimicrob Chemother 2009, 64:301-309.

26. Stolle I, Prenger-Berninghoff E, Stamm I, Scheufen S, Hassdenteufel E, Guenther S, Bethe A, Pfeifer Y, Ewers C: Emergence of OXA-48 carbapenemase-producing Escherichia coli and Klebsiella pneumoniae in dogs. J Antimicrob Chemother 2013, 68:2802-2808.

27. Woodford N, Wareham DW, Guerra B, Teale C: Carbapenemase-producing Enterobacteriaceae and non-Enterobacteriaceae from animals and the environment: an emerging public health risk of our own making? J Antimicrob Chemother 2014, 69:287-291.

28. Fischer J, Rodriguez I, Schmoger S, Friese A, Roesler U, Helmuth R, Guerra B: Salmonella enterica subsp. enterica producing VIM-1 carbapenemase isolated from livestock farms. J Antimicrob Chemother 2013, 68:478-480

29. Shi W, Li K, Ji Y, Jiang Q, Wang Y, Shi M, Mi Z: Carbapenem and cefoxitin resistance of Klebsiella pneumoniae strains associated with porin OmpK36 loss and DHA-1 $\beta$-lactamase production. Braz J Microbiol 2013, 44:435-442.

30. Livermore DM: CTX-M: changing the face of ESBLs in the UK. J Antimicrob Chemother 2005, 56:451-454

31. Geser N, Stephan R, Hächler H: Occurrence and characteristics of extended-spectrum $\beta$-lactamase (ESBL) producing Enterobacteriaceae in food producing animals, minced meat and raw milk. BMC Vet Res 2012, 8:21.

32. Ilse $\mathrm{O}$ : Extended-spectrum $\beta$-lactamase genes of Escherichia coli in chicken meat and humans, the Netherlands. Emerg Infect Dis 2011, 17:1216-1222.

33. Hordijk J, Schoormans A, Kwakernaak M, Duim B, Broens E, Dierikx C, Mevius D, Wagenaar JA: High prevalence of fecal carriage of extended spectrum $\beta$-lactamase/AmpC-producing Enterobacteriaceae in cats and dogs. Front Microbiol 2013, 4:242

34. Poirel L, Nordmann P, Ducroz S, Boulouis HJ, Arne P, Millemann Y Extended-spectrum- $\beta$-lactamase CTX-M-15-producing Klebsiella pneumoniae of sequence type ST274 in companion animals. Antimicrob Agents Chemother 2013, 57:2372-2375.

35. Johns I, Verheyen K, Good L, Rycroft A: Antimicrobial resistance in faecal Escherichia coli isolates from horses treated with antimicrobials: A longitudinal study in hospitalised and non-hospitalised horses. Vet Microbiol 2012, 159:381-389.

36. Dierikx CM, van Duijkeren E, Schoormans AHW, van Essen-Zandbergen A, Veldman K, Kant A, Huijsdens XW, van der Zwaluw K, Wagenaar JA, Mevius $D J$ : Occurrence and characteristics of extended-spectrum- $\beta$-lactamaseand $\mathrm{AmpC}$-producing clinical isolates derived from companion animals and horses. J Antimicrob Chemother 2012, 67:1368-1374.

37. Smet A, Boyen F, Flahou B, Doublet B, Praud K, Martens A, Butaye P, Cloeckaert A, Haesebrouck F: Emergence of CTX-M-2-producing 
Escherichia coli in diseased horses: evidence of genetic exchanges of blaCTX-M-2 linked to ISCR1. J Antimicrob Chemother 2012, 67:1289-1291.

38. Ferreira JC, Penha Filho RAC, Andrade LN, Berchieri A, Darini ALC: Cutler: Detection of chromosomal blaCTX-M-2 in diverse Escherichia coli isolates from healthy broiler chickens. Clin Microbiol Infect 2014, doi:10.1111/14690691.12531. published ahead of print.

39. Berman H, Barberino MG, Moreira ED, Riley L, Reis JN: Distribution of strain type and antimicrobial susceptibility of Escherichia coli causing meningitis in a large urban setting in Brazil. J Clin Microbiol 2014, doi:10.1128/JCM.03104-13. JCM.03104-13; published ahead of print.

40. Burke L, Hopkins KL, Meunier D, de Pinna E, Fitzgerald-Hughes D, Humphreys $\mathrm{H}$, Woodford N: Resistance to third-generation cephalosporins in human non-typhoidal Salmonella enterica isolates from England and Wales, 2010-12. J Antimicrob Chemother 2014, 69:977-981.

41. Yang T, Zeng Z, Rao L, Chen X, He D, Lv L, Wang J, Zeng L, Feng M, Liu JH: The association between occurrence of plasmid-mediated quinolone resistance and ciprofloxacin resistance in Escherichia coli isolates of different origins. Vet Microbiol 2014, 170:89-96.

42. Poirel L, Cattoir V, Nordmann P: Plasmid-Mediated Quinolone Resistance; Interactions between Human, Animal, and Environmental Ecologies. Front Microbiol 2012, 3:24.

43. Chaves J, Ladona MG, Segura C, Coira A, Reig R, Ampurdanés C: SHV-1 beta-lactamase is mainly a chromosomally encoded species-specific enzyme in Klebsiella pneumoniae. Antimicrob Agents Chemother 2001, 45:2856-2861.

44. Mshana SE, Hain T, Domann E, Lyamuya EF, Chakraborty T, Imirzalioglu C Predominance of Klebsiella pneumoniae ST14 carrying CTX-M-15 causing neonatal sepsis in Tanzania. BMC Infect Dis 2013, 13:466.

45. Leistner R, Sakellariou C, Gürntke S, Kola A, Steinmetz I, Kohler C, Pfeifer Y, Eller C, Gastmeier P, Schwab F: Mortality and molecular epidemiology associated with extended-spectrum $\beta$-lactamase production in Escherichia coli from bloodstream infection. Infect Drug Resist 2014, 7:57-62.

46. Shahid M, Singh A, Sobia F, Rashid M, Malik A, Shukla I, Khan HM: BlaCTX-M, blaTEM, and blaSHV in Enterobacteriaceae from North-Indian tertiary hospital: high occurrence of combination genes. Asian Pacific J Tropical Med 2011, 4:101-105.

47. Munday CJ: Predominance and genetic diversity of community- and hospital-acquired CTX-M extended-spectrum $\beta$-lactamases in York, UK. J Antimicrob Chemother 2004, 54:628-633.

48. Cantón R, Coque TM: The CTX-M $\beta$-lactamase pandemic. Curr Opin Microbiol 2006, 9:466-475.

49. Sabtcheva S, Kaku M, Saga T, Ishii Y, Kantardjiev T: High prevalence of the aac $\left(6^{\prime}\right)-\mathrm{lb}$-cr gene and its dissemination among Enterobacteriaceae Isolates by CTX-M-15 plasmids in Bulgaria. Antimicrob Agents Chemother 2009, 53:335-336.

50. Shibl AM, Al-Agamy MH, Khubnani H, Senok AC, Tawfik AF, Livermore DM: High prevalence of acquired quinolone-resistance genes among Enterobacteriaceae from Saudi Arabia with CTX-M-15 $\beta$-lactamase. Diagn Microbiol Infect Dis 2012, 73:350-353.

51. European center for disease prevention and control (2012): Antibiotic resistance surveillance in Europe 2012. [www.ecdc.europa.eu]

52. Zhang L, Foxman B, Marrs C: Both urinary and rectal Escherichia coli isolates are dominated by strains of phylogenetic group B2. J Clin Microbiol 2002, 40:3951-3955.

53. Picard B, Garcia JS, Gouriou S, Duriez P, Brahimi N, Bingen E, Elion J, Denamur E: The Link between phylogeny and virulence in Escherichia coli extraintestinal infection. Infect Immun 1999, 67:546-553.

54. Karisik E, Ellington MJ, Livermore DM, Woodford N: Virulence factors in Escherichia coli with CTX-M-15 and other extended-spectrum -lactamases in the UK. J Antimicrob Chemother 2007, 61:54-58.

55. Valat C, Auvray F, Forest K, Metayer V, Gay E, Garam C, Madec JY, Haenni M: Phylogenetic grouping and virulence potential of extended-spectrum- $\beta$ lactamase-producing Escherichia coli strains in cattle. Appl Environ Microbiol 2012, 78:4677-4682

56. Yang YS, Ku CH, Lin JC, Shang ST, Chiu CH, Yeh KM, Lin CC, Chang FY: Impact of extended-spectrum $\beta$-lactamase-producing Escherichia coli and Klebsiella pneumoniae on the outcome of community-onset bacteremic urinary tract infections. J Microbiol Immunol Infect 2010, 43:194-199.

57. Martínez-Martínez L, Pascual A, Jacoby GA: Quinolone resistance from a transferable plasmid. Lancet 1998, 351:797-799.
58. Hartmann A, Locatelli A, Amoureux L, Depret G, Jolivet C, Gueneau E, Neuwirth C: Occurrence of CTX-M producing Escherichia coli in soils, cattle, and farm environment in France (Burgundy region). Front Microbiol 2012, 3:83.

59. Guenther S, Ewers C, Wieler LH: Extended-spectrum beta-lactamases producing $E$. coli in wildlife, yet another form of environmental pollution? Front Microbio 2011, 2:246.

60. Huber H, Zweifel C, Wittenbrink MM, Stephan R: ESBL-producing uropathogenic Escherichia coli isolated from dogs and cats in Switzerland. Vet Microbiol 2013, 162:992-996.

61. Dahmen S, Haenni M, Chatre P, Madec JY: Characterization of blaCTX-M IncFIl plasmids and clones of Escherichia coli from pets in France. J Antimicrob Chemother 2013, 68:2797-2801.

62. Dierikx C, van der Goot J, Fabri T, van Essen-Zandbergen A, Smith H, Mevius $D$ : Extended-spectrum- $\beta$-lactamase- and AmpC- $\beta$-lactamase-producing Escherichia coli in Dutch broilers and broiler farmers. J Antimicrob Chemother 2013, 68:60-67.

63. Calistri P, lannetti S, Danzetta M, Narcisi V, Cito F, Di Sabatino D, Bruno R, Sauro F, Atzeni M, Carvelli A, Giovannini A: The components of 'one world - one health' approach. Transbound Emerg Dis 2013, 60:4-13.

\section{doi:10.1186/1471-2180-14-187}

Cite this article as: Schmiedel et al:: Multiresistant extended-spectrum $\beta$-lactamase-producing Enterobacteriaceae from humans, companion animals and horses in central Hesse, Germany. BMC Microbiology 2014 $14: 187$.

\section{Submit your next manuscript to BioMed Central and take full advantage of:}

- Convenient online submission

- Thorough peer review

- No space constraints or color figure charges

- Immediate publication on acceptance

- Inclusion in PubMed, CAS, Scopus and Google Scholar

- Research which is freely available for redistribution 